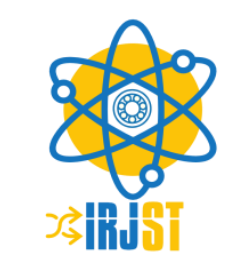

Available online at https://www.irjst.com/

International Research Journal of Science and Technology

ISSN: 2707-3955

DOI: https://doi.org/10.46378/irjst.2020.010402

\title{
Forensic Entomology: an inventory of Arthropods collected on the decomposing pig Carrions during the dry season in Warri, Southern Nigeria
}

\section{Odo P.E ${ }^{1 *}$ and Iloba B. $\mathbf{N}^{1}$}

${ }^{1}$ Department of Animal and Environmental Biology, Faculty of Life Sciences, University of Benin, Benin City, Edo

State, Nigeria.

\begin{tabular}{llll}
\multicolumn{2}{l}{ Paper Status } & & \\
Received : & Aug 2020 \\
Accepted : & Sep 2020 \\
Published : & Sep 2020
\end{tabular}

Key Words

Arthropods,

Coleoptera

Decomposition

Entomofauna

Hymenoptera

Post-Mortem Interva

Stages Of Decomposition

\begin{abstract}
Arthropods found on the pig carrions in the dry season in the Warri city at $05^{\circ} 32^{\prime} 34.95^{\prime \prime} \mathrm{N}$ and $05^{\circ} 44^{\prime} 39.834^{\prime \prime} \mathrm{E}$ from 10th December 2017 to 10th February 2018 studied. Three pigs were killed and their decomposition monitored for 60 days, arthropods were collected with the aid of sweep nets, brushes, handpicking and pitfall traps while the soil below the decaying pig carrions were searched extensively twice daily for the first week and once daily for the remaining weeks. Data analysis was done by Microsoft excel while graphs were used to demonstrate the frequencies of the arthropods in every phase of decomposition, pie chart was used to elucidate stages of putrefaction and their respective periods. The outcome of the study showed five exclusive stages of decay: fresh, bloated, active decay, advance decay and dry decay correspondingly. The fresh stage took shortest days of 2 as the dry decay took longest days of 41 . A total of 1495 arthropods were collected, at the fresh stage, there were 244 arthropods, while 213 were Diptera, only 19 were Hymenoptera and 12 were also Coleoptera but at the bloated stage of decomposition, a total of 273 arthropods were recorded, Diptera were 223 as hymenoptera were 21 and Coleoptera were 29 while at the active decay stage of decomposition there were a total of 437 arthropods, 333 of them were Diptera, 29 were Hymenoptera as 75 were Coleoptera but at the advance decay stage of decomposition, there were a total of 438 arthropods, 225 of them were Diptera, 30 were Hymenoptera as 91 were Coleoptera but at the dry decay stage of decomposition, only 195 arthropods were recorded, 96 of them were Diptera, 21 were Hymenoptera and 78 were Coleoptera in that order, for the reason that the Coleoptera and Diptera used the decaying pig carrions for breeding of their offspring, they could be used in the estimation of the time after death hence are of immense forensic importance while the role of the recorded Hymenoptera could also be of great importance as the tears and wears that they created on the carrions could be cause of error in the estimation of the time of death and their predatory role could also give a fake entomofauna documentation data, more researches of this nature are to be carried out in Warri city and other neighboring communities in order to document reliable database of arthropod of forensic importance in the oil rich city.
\end{abstract}

Copyright (C) 2020: Odo P.E and Iloba B.N.This is an open-access distribution, and reproduction in any medium provided Access article distributed under the Creative Commons Attribution License the original work is properly cited License, which permits unrestricted use.

Citation: Odo P.E and Iloba B.N. "Forensic Entomology: an inventory of Arthropods collected on the decomposing pig Carrions during the dry season in Warri, Southern Nigeria". International Research Journal of Science and Technology, 1 (4), 277-285, 2020 .

\section{Introduction}

One thing that is sure in life is the demise of an organism as it is certain that every living thing will one day die but the manner at which an individual dies and the latent fact surrounding his demise is very supreme in criminal investigation pertaining to bringing to light of the ingredients of the sort and details of the fastidious death. The creation of the database of arthropods' successions on decomposing pig carrions is very important for the successful implementation of 
the concept of forensic entomology in the investigation of these facts of death. When this documentation is properly done in an area or region, it makes it easier to apply this concept in the real life investigation pertaining to human death.

Hundreds of species of arthropods are always implicated with the decaying carrions mainly Coleoptera, Diptera, (adult and immature stages), ticks, mites, nematodes, millipedes among others. These organisms feed, dwell or lay eggs in and on the decaying animal bodies depending on their biological preferences and on the state of decay [1-5]. As long as these organisms are the largest and the most significant biological group on the planet earth, they are always ubiquitous; found in different environmental and location types even on the decaying animal bodies. This fact gives room for a wide range of usefulness for carrion ecological investigation applying arthropods especially the insects found on the cadavers and on the scene of the crime [6].

These arthropods found on the decaying animal bodies could be very useful in the determination of the cause of death, time of death (Post-mortem interval) and place of death. The insects and their products could also be used in the determination of the presence of toxins or poisons presence in the tissues of a death animal as well as the presence of drugs and other chemicals in the decaying organisms [7-10,3,4]. Decomposition process is a long and complex one as there is several stages and morphological changes that always take place during this process while different factors affect the process such as the temperature, climatic conditions, weather, rainfall, locations, accessibility of the carrion insects to the carrions, topography among others $[11,12]$. A comprehensive study of these insects collected on the decaying pig carrions will be a great and immense revelation of latent truths about death of an organisms, the main aim of this study is to comprehensively study the decaying process and the respective entomofauna found on the decaying pig carrions in the dry season at the Warri City so as to use the data base created for further forensic entomological investigation in the oil rich city.

\subsection{Literature review}

Carrion flies detach putrefying organisms' rich nutritive materials always; although some species are found in every environmental type, several others are scarcely native.

\footnotetext{
* Corresponding Author: Odo P.E

Department of Animal and Environmental Biology, Faculty of

Life Sciences, University of Benin, Benin City, Edo State.

Email: patrick.odo@lifesci.uniben.edu
}

Diverse groups of insects are found in dissimilar dwelling areas with some of them living in urban or rural areas but some live in both areas $[13,14]$. An amount of variables can influence post-mortem interval (PMI) estimates such as physical, chemical, climate, scavengers, toxins and physical barriers ([14] finally, there is always insects colonisation and decomposition. The concept of burying a body of a victim of assassination is a trendy physical barrier chosen by murderers who decide to dispose a body, a number of works have observed that these buried bodies decompose at a sluggish pace than those bare to the air $[15,16]$. These assailants hardly dig the graves deeper than $30 \mathrm{~cm}$ and $60 \mathrm{~cm}$, the reason for this is because they don't want to be trapped around their victims' decaying carrions. The appropriate examination of the entomofauna recovered on a decaying a body with the full familiarity of the prospect environmental variables such as temperature and relative humidity can often be a reliable forensic revelation [17]. These methods comprise the guess of the time after death occurred, disturbance or transferring the carrion after demise to more hidden place, suggestion of wounds and the existence of toxins among others. The decaying body attracts many insects and other arthropods in a prototype of relative consecutive way. Several professionals on carrion ecology have studied the decomposition processes including the successive wave of insects communities on the decomposing bodies using different animal model, Pig known as (Sus scrofa Linn.) is a frequently used animal model in this type of studies although the world $[10,18,15]$.

The reasons for using them here are because pigs are always found easily and the replication of the same body sizes of the pigs during a research work is very easy as they are most often seen together with the consistency of the body size particularly when they are of the same mother and same age. These pigs have mono-gastric alimentary canal and have fur system that resembles that of man; these points make them exceptionally comparable to man than any other animal [19]. Several other animal models apart from these pigs have equally been used in the forensic entomological studies as human models by several authors, they include, rabbits, cats, dogs, mice, birds, turtle, and elephants while parts of the animals bodies such as pork, beef, liver of goats, liver of cow, blood of goats, blood of cows, ice fish, fresh fish etc.[20$22 ; 10,23 ; 23-26,5,17]$.

\subsection{Experimental procedures, Materials and methods}

\subsection{Study site}

This study took place in the Biological Science Departmental garden of the College of Education, 
Warri, Delta State, $05^{\circ} 32^{\prime} 34.95^{\prime \prime N}$ and 05 44'39.834"E from 10th June to 10th August 2018 The measurement of this study site approximated 300 $\mathrm{x} 200 \mathrm{~m}$, this size was to minimise overlapping olfactory cues among neighbouring cadavers.

\subsection{The Experimental Set-up for the Succession Studies}

Three pigs were used in this study, each pig was stabbed in the thorax, under the foreleg with a sharp knife to simulate a typical homicide wound, each killing was around $6.00 \mathrm{pm} \mathrm{a}$ day before the commencement of this research work and the day of their death was counted as day 0 on each trial. The carrions were placed into heavy trash bags and carried from the killing place to the studying site.

The pig carrions were deposited on the ground, guarded against vertebrate scavengers with wire mesh that permits entrance of all the insects and other arthropods and protected the carrions against the other bigger animals. The wire meshes of $160 \mathrm{~mm} \times 100 \mathrm{~mm} x$ $30 \mathrm{~mm}$ were used to form iron cages that were removed on each sampling occasions. There were an inter carcass distances of $40 \mathrm{~m}$ to minimise interruption of flies from adjacent carrions.

\subsection{Insects Sampling Methods and Data Collection in the Succession Studies}

The samples for the entomo fauna were from 10th December 2017 to 10th February 2018, was carried out two times per day at 10 and 14.00 GMT for the initial week while once daily for the remaining weeks. Insects were collected manually through the use of hand nets, sweep nets for flying insects, these flying insects were collected by making fifteen swings with the sweep net in each sampling occasion, while brushes were used to comb round the animal bodies to collect those insects that were found on the bodies and hand picking were also used manually, pitfall traps for crawling insects while the soil just under the decomposing carrions were always scanned to collect any stage of insect found pupating or hiding around.

Second instars larvae were collected from the decaying carrions and the larvae from each carrion were bred in the transparent plastic containers with depth of $15 \mathrm{~cm}$ and width diameter of $11.5 \mathrm{~cm}$ at $25.0 \mathrm{C}$ each (with muslin cloth covering and rubber bands that permitted ventilation and hindered the escape of the insects) containing saw-dust and part of the decaying carrionremains to feed the immature insects, the second instars larvae were reared till adult stage. The adult insects that emerged from the rearing containers were collected with forceps instantaneously after the nurture cloth was disconnected and preserved in $80 \%$ ethanol respectively while the emerged adult beetles and flies were sorted to their taxonomic groups for classification, identification and for further studies.

\subsection{Data Analysis}

Data Analysis was performed through Microsoft Excel, graphs were used to demonstrate relationship between one variable and the other while Principle component Analysis (PCA) was used to compare the distribution of frequency of occurrence of species at the different stages of decomposition of the pig carrions

\subsection{Insects Identification}

Existing keys of identification of insects were applied in the identification of the insects that were collected in this research work:

Different Orders, family, species and genus were identified [27,28].For Diptera [29-33] Lepidoptera: [34].Coleoptera: [35-38]. For Hymenoptera [39-42].

\subsection{Results}

4.1The Carrion decomposition pattern and entomofauna of the different stages of decomposition The first insect species to visit the exposed pig carrion was the L. sericata, it arrived at the scene at about 6.20 minutes after exposure. At this stage of decomposition, it took only 2 days from day 0 to day 2 (Table 1). 244 insects were observed, while 213 of them were Diptera, 19 were Hymenoptera and 12 were Coleoptera respectively (Figure1). The bloat stage started on the day 3 and ended on the day 5, took only 3 days, the active decay stage started on the day 6 and stopped on the day 12 (7days), while the advanced decay stages started on the day 13 and ended on the 18 (6 days), the dry decay stage started on the day 19 and ended on the day 60 respectively.

A total of 1495 insects were collected during the study, at the fresh stage, 244 were encountered, 213 were Diptera, and 19 were Hymenoptera, while only 12 of them were Coleoptera. At the bloated stage, 273 insects were encountered, 223 were Diptera and 21 were Hymenoptera, while 29 were Coleopteran. At the active decay stage of decomposition, 437 insects were recorded, 333 were Diptera and 29 were Hymenoptera while 75 were Coleoptera. At the advanced decay stage, 436 insects were recorded, 225 were Diptera and 30 were Hymenoptera while 91 were Coleoptera. However at the dry decay/skeletal stage of decomposition, 195 insects were recorded, 96 were Diptera and 21 were Hymenoptera and 78 were Coleoptera.

At the fresh stage of decomposition, there were no observed sign of decomposition on the carrions and no insects were recorded on the first 3 minutes of the displaying the pig carrions, but after about 6 minutes 
the insects started arriving the scene of the incident (Table 1).

No recorded physiochemical changes bodily on the decomposing carcasses. The initial groups of arthropods that visited the decaying pig cadavers belong to the order Dipterans, immediately 6.20minutes after death. These were Muscidae, Calliphoridae, Sarcophagidae, Fannidae and Staphylinidae, they oviposited in clusters at a range of body openings such as mouth, nose, anus, unrinogenital organs.

At the bloated stage of decomposition, (Table 2). There existed perceptible physiochemical and morphological alterations: puffiness of the bodies of the dead pigs, oozing out of watery fluids from ordinary and artificial openings and distasteful smells were features of this phase of the pigs' decay. The important arthropod members here were larvae of members of Calliphoridae, Sarcophagidae, Muscidae, Drosophilidae, Staphylinidae, Cleridae and Formicidae majorly of their initial first and second instars' larvae jointly.

At the active decay stage of decomposition. This decay phase exhibited offensive odour, decaying tissues of the pigs have shrunken, and carcasses become much fluid and watered-down but still fresh. Almost all the Dipterans recorded during this phase of decay were also a larvae stage though fewer adult were collected compared to the two previous phases. Hymenopterans particularly members of Formicidae families were also noticeable at this stage of decay. There were also very handy numbers of adults of the Order Coleoptera collected during this phase of decay. This phase exhibited highest number of arthropods in the whole decay regime, and it indicates the second wave of arthropods sequence on the pig carrions. At the Advance decay stage of decomposition, Wet decay stage: this decomposition stage was characterized by little odor, decomposing tissues have completely collapsed, carrions become very little fluid and watery, hence advanced decay stage of decay. Most Dipterans found at this stage are in their adult and few in their larval stages in comparison to the three earlier stages.

Hymenopterans especially members of Formicidae families were also noticeable at this stage of decomposition. Adult of the Order Coleoptera were recorded at this stage of decay. This stage showed good number of insects and it showed the third sign of arthropods succession. The irrefutable condition of this phase of decay finished with the 3rd instars larvae leaving the carrions for pupation (Table 4). At the dry decay stage of decomposition, the putrefaction of the pig carrions at this phase indicated predominant arthropod order here of the Coleoptera and the Hymenoptera. The Coleopterans were represented by the members of Histeridae, Cleridae and Dermestidae, in addition at this phase of decay were the empty puparium of Dipterans that were much just about the relics and their immediate vicinity.

It was also observed that the Coleopterans were present as adults and larvae being symptomatic of the dry decay stage, it was assumed that they were breed from the decaying pig carrions.

\subsection{The Decomposition Period of the Pig Carcasses}

The fresh stage of decay of the pig carrions began on day 0 being the day the animal was strangulated and closed on the primary symptom of bloat at day 2; taking just two days and 3\% of the whole putrefaction phase, whereas bloat phase of the pig decay began at the 3rd and stooped at the 5th day; lasted for only 3 days and was $5 \%$ of the entire time of decay, while active decay phase of decay began on the 6th but ended on 12th day; took 7days and $12 \%$ of total decay time but advance decay phase began on 13th day and ended on 18th, took only 6days and $10 \%$ of the whole time of decay as dry decay phase began on 19th day but stopped on 60th and took 41days and $70 \%$ of the time of decay (Figure 1).

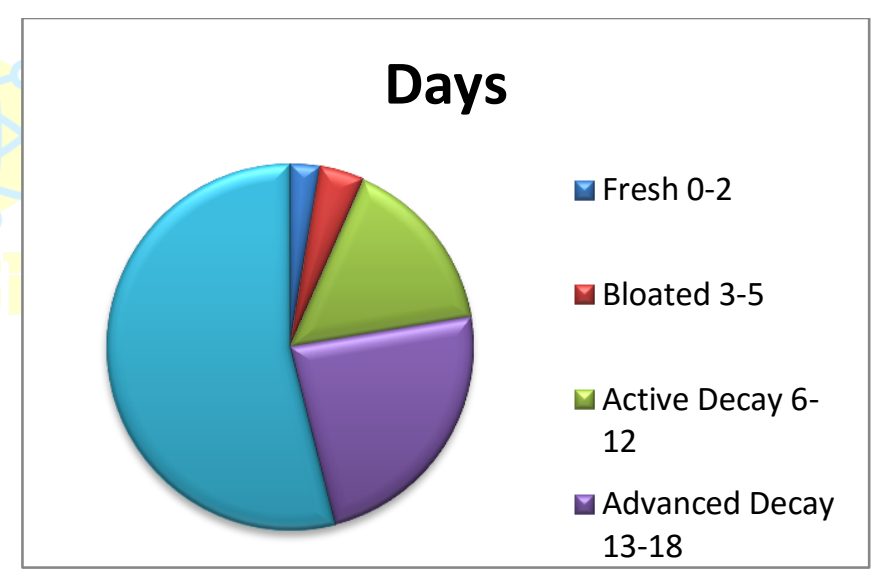

Figure 1.The period of decomposition of pig carrion

\subsection{Frequency of occurrence of insect orders encountered at stages of decomposition}

In the track of this study, 1495 arthropods were collected, out of this number 244 of them were collected during at the initial fresh stage of decay (Table 1) as 273 of them were also collected during the second stage: the bloated stage (Table 2) and during the active stage 437 were collected (Table 3 ) and 346 were collected during the advanced decay stage (Table 4) as only 195 of them were recorded during dry decay stage of decay (Table 5). Meanwhile during the fresh stage of decay, among the 244 arthropods assembles, there were only 213 Dipterans, 19 Hymenopterans as only 12 of the Coleopterans and during the bloat stage of decay, among the 273 recorded, there were only 223 Diptera, 21 Hymenoptera and 29. 
Table1. Entomofauna of the Fresh Stage

\begin{tabular}{lllll}
\hline Order & Family & Genus/species & Life stage & Number \\
Diptera & Muscidae & M. domestica & A & 24 \\
Diptera & Muscidae & H. minuta & A & 9 \\
Diptera & Muscidae & A. occidentalis & A & 4 \\
Diptera & Sarcophagidae & Sarcophaga sp. & A, I & 12 \\
Diptera & Sarcophagidae & S. tibalis & A, I & 9 \\
Diptera & Sarcophagidae & S. inzi & A, I & 2 \\
Diptera & Calliphoridae & L. sericata & A, I & 31 \\
Diptera & Calliphoridae & C. albiceps & A,I & 47 \\
Diptera & Calliphoridae & C. megacephala & A, I & 27 \\
Diptera & Calliphoridae & C. vomitotria & A, I & 16 \\
Coleoptera & Staphylinidae & S. violaceous & A & 12 \\
Hymenoptera & Formicidae & M. senaarensis & A & 18
\end{tabular}

$* * \mathrm{~A}=$ adults, $\mathrm{I}=$ immature

Table 2. Entomofauna of the bloated stage of decomposition

\begin{tabular}{lllll}
\hline Order & Family & Genus/species & Life stage & Number \\
\hline Diptera & Calliphoridae & C. albiceps & A, I & 31 \\
Diptera & Calliphoridae & C. chloropyga & A,I & 24 \\
Diptera & Calliphoridae & L. sericata & A, I & 27 \\
Diptera & Fannidae & Fannia sp & A & 25 \\
Diptera & Sarcophagidae & Sarcophaga sp & A, I & 17 \\
Diptera & Sarcophagidae & S. inzi & A, I & 20 \\
Diptera & Sarcophagidae & S. exuberans & A & 5 \\
Diptera & Muscidae & M. domestica & A & 25 \\
Diptera & Muscidae & Haematobia minuta & A & 9 \\
Diptera & Drosophilidae & Drosophilia spp & A, I & 32 \\
Coleoptera & Staphylinidae & Philonthus sp. & A & 6 \\
Coleoptera & Cleridae & N. ruficolis & A & 11 \\
Coleoptera & Cleridae & N. rufipes & A & 12 \\
Hymenoptera & Formicidae & M. senaarensis & A & 12 \\
Hymenoptera & Formicidae & Camponotus pennsylvanicus & A & 9 \\
\hline
\end{tabular}

** $\mathrm{A}=$ adults, $\mathrm{I}=$ immature

Table 3. Entomofauna of the Active Decay stage of decomposition

\begin{tabular}{lllll}
\hline Order & Family & Genus/ Species & Life stage & Number \\
\hline Diptera & Muscidae & M. domestica & A, I & 31 \\
Diptera & Muscidae & Hydrotae sinigera & A & 12 \\
Diptera & Muscidae & Haematobia minuta & A & 21 \\
Diptera & Sarcophagidae & Sarcophaga sp. & A, I & 22 \\
Diptera & Sarcophagidae & S. tibalis & A, I & 19 \\
Diptera & Sarcophagidae & S. inzi & A. I & 26 \\
Diptera & Sarcophagidae & S. exuberans & A, I & 11 \\
Diptera & Calliphoridae & L. sericata & A, I & 33 \\
Diptera & Calliphoridae & C. albiceps & A, I & 38 \\
Diptera & Calliphoridae & C. megacephala & A, I & 12 \\
Diptera & Calliphoridae & C. chloropyga & A, I & 21 \\
Diptera & Calliphoridae & Calliphora vomitoria & A & 13 \\
Diptera & Fannidae & Fannia caricularis & A, I & 23 \\
Diptera & Fannidae & Fannia sp. & A, I & 19 \\
Diptera & Stratiomyidae & H. illucens & A, I & 32 \\
Hymenoptera & Formicidae & M. senaarensis & A & 12 \\
Hymenoptera & Formicidae & C. pennsylvanicus & A & 17 \\
\hline
\end{tabular}




\begin{tabular}{lllll}
\hline Order & Family & Genus/ Species & Life stage & Number \\
\hline Coleoptera & Cleridae & N. rufipes & A & 12 \\
Coleoptera & Cleridae & N. ruficolis & A & 27 \\
Coleoptera & Chrysomelidae & Pagia litura & A & 10 \\
Coleoptera & Dermestidae & D. maculatua & A & 19 \\
Coleoptera & Dermestidae & D. ater & A & 7 \\
\hline
\end{tabular}

$$
\text { ** } \mathrm{A}=\text { adults, } \mathrm{I}=\text { immature }
$$

Table 4. Entomofauna of the Advance Decay stage of decomposition

\begin{tabular}{lllll}
\hline Order & Family & Genus/Species & Life stage & Number \\
\hline Diptera & Muscidae & M. domstica & A, I & 25 \\
Diptera & Muscidae & H. minuta & A, I & 17 \\
Diptera & Sarcophagidae & Sarcophaga sp & A, I & 12 \\
Diptera & Sarcophagidae & S. tibalis & A, I & 15 \\
Diptera & Sarcophagidae & S. exuberans & A, I & 9 \\
Diptera & Calliphoridae & L. sericata & A, I & 15 \\
Diptera & Calliphoridae & C. albiceps & A, I & 16 \\
Diptera & Calliphoridae & C. megacephala & A, I & 4 \\
Diptera & Calliphoridae & C. rufifacies & A & 2 \\
Diptera & Calliphoridae & C. vomitoria & A & 6 \\
Diptera & Statiomyidae & H. illucens & A, I & 65 \\
Coleoptera & Cleridae & N. ruficolis & A & 16 \\
Coleoptera & Cleridae & N. rufipes & A & 22 \\
Coleoptera & Dermestidae & D. maculatus & A, I & 11 \\
Coleoptera & Dermestidae & D. ater & A & 3 \\
Coleoptera & Histeridae & H. monitor & A & 12 \\
Coleoptera & Scrabeidae & Onthophagous sp & A & 06 \\
Coleoptera & Staphylinidae & Philonthus sp. & A & 21 \\
Hymenoptera & Formicidae & M. senaarensis & A & 18 \\
Hymenoptera & Formicidae & Camponotus sp & A & 12 \\
\hline
\end{tabular}

Table 5. Entomofauna of the Dry Decay stage of decomposition

\begin{tabular}{lllll}
\hline Order & Family & Genus/ species & Life stage & Number \\
\hline Coleoptera & Cleridae & N. ruficolis & A, I & 22 \\
Coleoptera & Cleridae & N. rufipes & A, I & 18 \\
Coleoptera & Dermestidae & D. maculatus & A, I & 15 \\
Coleoptera & Dermestidae & D. ater & A, I & 11 \\
Coleoptera & Staphylinidae & Philonthus sp. & A, I & 16 \\
Coleoptera & Histeridae & H. monitor & A & 16 \\
Diptera & Calliphoridae & C. albiceps & A & 5 \\
Diptera & Calliphoridae & C. rufifacies & A & 4 \\
Diptera & Calliphoridae & L.sericata & A & 6 \\
Diptera & Sarcophagidae & S.inzi & A & 2 \\
Diptera & Sarcophagidae & S. exuberans & A & 5 \\
Diptera & Muscidae & M. domestica & A & 6 \\
Diptera & Stratiomyidae & H. illucens & A, I & 48 \\
Hymenoptera & Formicidae & M. senaarensis & A & 21 \\
\hline
\end{tabular}

Nevertheless, during the active decomposition stage, among the 437 arthropods assembled there, there 33 Diptera, 29 Hymenoptera and 75 but during the advanced decomposition stage, among the 346 arthropods recorded, there were 225 Diptera, 30
Hymenoptera as only 91 Coleoptera were collected but at the dry decay stage of decay, among the 195 arthropods assembles, there were 96 Diptera, 21 Hymenoptera and 78 Coloeptera (Figure 2). 


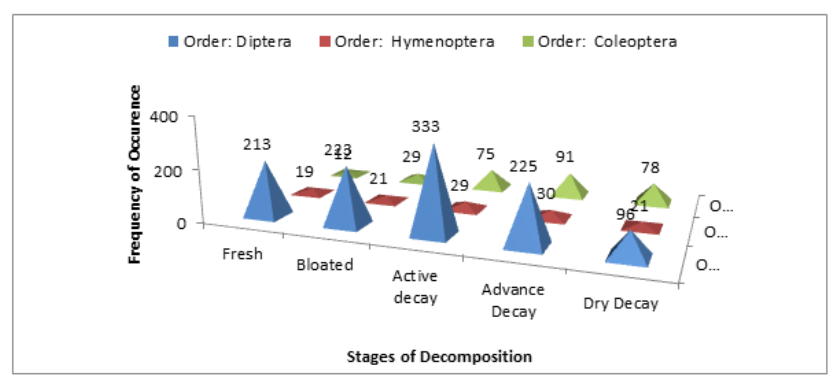

Figure 2. Frequency of occurrence of insect orders recorded at stages of decomposition

\section{Discussion}

In this study, despite the fact that at the initial period of the pigs' decomposition, it seemed like arthropods were not going to invade the pig carrions, in 6 minutes time $L$. sericata visited the carrion hereafter other insects species were able to visit the carrion equally. There were only three orders of insects recorded on the pig carrions during this decay process whereas the Diptera were the highest insects collected on the decaying carrions, the Hymenoptera were the least recorded. There were also five distinctive stages of decomposition observed during the pigs' decomposition, in spite of the fact that decomposition process is just an unbroken system, it has been broken down into different stages for ease of study and identification. The observed stages were fresh, bloated, active decay, advance decay and dry decay stages respectively. Other scholars of carrion environmental biology have recorded different stages of decomposition majorly between four and five stages $[3,4,12]$ observed five stages of decomposition even on a smaller carrion type while the result is different from $[11,43]$ that recorded four stages of decomposition in South Africa which could be attributed to differences in the climatic conditions.

The predominant insects group in this study was the Diptera followed by Coleoptera while hymenoptera were the least group of insects collected during this study. While the Calliphoridae, Sarcophagidae and Stratiomyidae made the highest groups collected on the pig carrions Formicidae of the order of Hymenoptera were the least species on the carrions. $[2-5,10,12,44,45]$ among other researchers on forensic entomology have also recorded that Diptera were the most predominant insect order collected on decaying carrion in different regions and climatic conditions, these Diptera and Coleoptera groups are necrophages hence could be used in the determination of the time after death while Hymenoptera (Formicidae) were of less forensic importance though many carrion ecologists have not reported the role of this group of insects in decomposition process, they are predators of other carrions insects, carries both the immature and adult stages away from the carrions hence could be a cause of under reporting of the insects found on the carrions and could also cause tears and wears capable of creating artificial orifices on the carrion that could also create avenues for the insects oviposition hence may be a cause of great errors in the determination of the post mortem interval. This is in accordance with the finding of $[3 ; 4]$

Absolute carefulness must be taken while studying the insects of forensic importance on the decomposing carrion, the role of ants in altering the entomofauna numbers and species collected on the carrions as well as the tears and wears they cause on the carrion and its effects on causing distortion in the immediate PMI estimation should not be underrated if the best result should be achieved in the use of insects in the determination of the place of death, time of death and cause of death.

\section{Conclusion}

Nearly all of the arthropods' species collected during this study have been reported by other scholars of carrion ecology in nationally and internationally. The outcome of this current study has indicated that an allencompassing and suitable compilation of the arthropods observed on dead bodies, and their products or stages of life, are crucial for the utmost usefulness of insects in carrion ecological investigation. This present study has however created good record of entomofauna of great importance on decaying pig carrion in Warri city and its neighboring communities that will be available for future researchers' usage, for the utilization of the lawyers, law officers, law enforcement agents, criminal investigators and students for consultation as a bench mark and comparative ground whenever the concept of forensic entomology is to be applied in the investigation of hidden truth in dead types, rapes and other crimes in the oil rich city.

\section{Acknowledgment}

The authors wish to acknowledge the management of College of Education Warri for enabling us to use their facility all through our research work

\section{Conflict of Interest}

There was no conflict of interest between the authors

\section{References}

[1]. Deonier, C. C (1940). Carcass temperatures and their relationship to winter blowfly populationsand activities in South West. J. Econ. Entomol. 33: 166 - 170.

[2]. Okiwelu, S.N., Ikpamini, T and Umezor, O.C. (2008). Arthropods associated with mammaliancarcasses in Rivers State, Nigeria. African Journal of BiomedicalResearch, 11: $339-342$ 
[3]. Odo, P.E. and Iloba, B.N. (2020a). A Wet Season Study of Insects' Community and putrefyingmanner of Rabbit (Oryctolagus cuniculus) Carcasses at the College of Education, Warri,Delta State, Nigeria. J. Mater. Environ. Sci., 2020, Volume 11, Issue 6, Page 885-895. http://www.jmaterenvironsci.com

[4]. Odo, P.E. and Iloba, B.N. (2020b). Insects' Succession on the Decomposing Pig Carrion during theWet Season at the College Of Education, Delta State, Nigeria. Samuel Adegboyega University Journal of Science and Technology (SAU Sci-Tech. J) 2020, 5(1)

[5]. Odo, P. E, Chidi, O. H. and Iloba, B. N. (2017). Insects Fauna Associated with decomposing RabbitCarrion in Falcorp Mangrove Park, Ijala, Warri, Delta State, Nigeria. Book of Proceeding of the Faculty of Science international Conference of the delta state University, Abraka,

[6]. Benecke, M. and Lessig, A. (2001). A brief history of forensic entomology. Forensic Science International 120:2-14

[7]. Smith, K. G. V. (1986). A Manual of Forensic Entomology. Trustees of the British Museum (Natural History), London.

[8]. Anderson, G. S., Sherah, V. (1999). Initial Studies on Insects' Succession on Carrion in Southwestern British Columbia.J. Forensic Sci. 41: $617-625$.

[9]. Goff, L., Miller, M., Paulson, J.D. Lord, W.D. Richard, E. and Amori, A. I. (1997). Effects of 3,4-Methylenedioxymethamphetamine in decomposing tissues on the development of parasarcophaga ruficolis (Diptera:

Sarcophagidae) and detection of drug in postmortemblood, liver tissue, larvae and puparia. J. Forensic Science 42:276 - 280

[10]. Ekrakene, T. and Odo, P.E. (2017) Comparative developmental effects of tramadolhydrochlorideandCypermethrine on Chrysomya albiceps (Dipera: Calliphoridae) reared on rabbitcarrion. Science world Journal 12 (1) 28-32. ISSN 15976343

[11]. Braack, L.E.O (1981). Visitation Patterns of principal species of insects-complex at carcasses in Kruger national park. Koedoe 24 : $33-49$.

[12]. Feugang, Y. F. D., Bilong, B.C.F., Cherix, D and Djito-Lordon, C. (2012). Biodiversity study ofarthropods collected onrabbit carrion in Yaounde, Cameroun: first study of forensic entomology in Central Africa. International Journal of Biosciences 2(1) 1 -8.

[13]. Haskell, N. H., Hall, R.D. Cervenka, V.J. and Clark, M.A.. (1997). On the body:insects'stage presence and their postmortem artifacts. Pp. 415-448 In: W.D

[14]. Grassberger, M. and Franck, C. (2004). Initial study of arthropod's succession on pig's carrion in a central Europe urban habitat. Journal of Medical Entomology 41 (3) 511 523.

[15]. Ekrakene, T. and Iloba, B.N. (2011). One death, Many Insects' generation. Journal of Entomology8 (1):27-39.

[16]. Payne, J. A. (1965). A summer carrion study of the baby pig Sus scrofa Linnaeus, Ecology, 46:592-602.

[17]. Pastula, E.M. (2013). Insects timing and Succession on buried carrions in East Lansing Michigan, an M. Sc thesis submitted to the Michigan state University

[18]. Abajue, M.C., Ewuim, S.C and Akunne, C.E (2014). Preliminary checklist of flies associated with pig carrions decomposing in Okija, Anambra State, Nigeria. Annual Research international 11 (1): 1899 - 1904.

[19]. Anderson, G., VanLaerhoven, S.L. (1996): Initial Studies on insects' succession on carrion inSouthwestern BritishColumbia. J. Forensic Sci. 41: 617 - 625

[20]. Denno, R. F. and Cothran, W. R. (1975). Niche Relationships of a Guild of Necrophagous Flies. Ann.Entomol. Soc. Am. 68741 - 754. 34. R. F

[21]. Villet, H. (2011). African carrion ecosystem and their insect communities in relation to forensic entomology. Pest Technology, 5 (11): $1-15$.

[22]. Nyasham, M., Masendu, R and Mawera, G. (2014). An initial study of insect succession ondecomposing rabbit carrions in Harare, Zimbabwe. Asia Pacific Journal of Tropical Biomedicine, 4 (7): 561 - 565.

[23]. Tekena, O. (2019). Insects of succession on Decomposing Guinea pig carrion at theCollege of Education, Warri, Delta State, Nigeria. A B.Sc (Ed). Project submitted tothe Delta State University, Abraka

[24]. Ekanem, M.S, Dike MC. (2010). Arthropod succession on pig carcasses in South Eastern Nigeria. Pap Avulsos Zool (Sao Paulo); 50(35):561-570.

[25]. Abell, D. H., S.S. Wasti and G.C. Hartmann. 1982. Saprophagous arthropod fauna associated with turtle carrion. Applications of Entomological Zoology 17: 301- 307.

[26]. Coe, M. 1978. The decomposition of elephant carcasses in the Tsavo (East) National Park, Kenya. Journal of Arid Environment 1: 71-86 
[27]. Arnett Jr, R. H and Jacques Jr., R. L. (1981). Simon and Shcuster's Guide to Insects. Simon and Schuster publishers, Newyork

[28]. Byrd, J. H. and Castner, J. L. (2001). Forensic Entomology, The Utility of Arthropods in Legal Investigations. CRC Press, Boca Raton, Fl

[29]. Shaumar, N. and Mohammad, S. (1983). Keys for identification of species of Family (Sarcophagidae:Diptera) in Egypt. J. Bull Soc Entomol .Egypt 64: 121 - 135

[30]. Shaumar, N. F. Mohammad, S. K. and Mohammad, S. A. (1998). Keys for identification of species of family Calliphoridae (Ditpera) in Egypt. J. Egypt Soc Parasitol.19 (2) 669-681

[31]. Oldroyd, H. (1964). The Natural History of Flies. London: Weidenfeld and Entomology 37: 253-272.

[32]. Zumpt, F. (1965). Myiasis in Man and Animals in the Old World, Butterworths, London.

[33]. Denno, R.F. and Cothran, W.R. (1975). Niche Relationships of a Guild of Necrophagous Flies. Ann.Entomol. Soc. Am. 68: 741-754.

[34]. 34. Torban, B. L. (2005). Butterfly of West Africa. Appolo Books, Kirkeby Sand 19, Dk 5771dtenstrup, Denmark.

[35]. Shaumar, N. F. Mohammad, S. K. and Salem, N. M. (1990). Taxonomic studies of Dermestidae(Coleoptera) in Egypt. J. BullSoc. Entomol. Egypt. 69: 11-12

[36]. Dillon, E. S and Dillon, L. S. (1961). A Manual of the Common Beetles of Eastern America.Evanston, Ill: Row, Peterson: p. 884.

[37]. Lawrence, J. F. and Newton Jr, A. F. (1982). Evolution and classification of beetles. Annual Review of Ecology and Systematics 13: 261290 https://doi.org/10.1146/annurev.es.13 .110182 .00140138

[38]. Almeida, M. L., Mise, K. M. (2009). Diagnosis and keys to the main families and species of SouthAmerica Coleoptera of Forensic important. Revista Brasileiva de Entomology 53(2) 227244) https://doi.org/10.1590/S00855626200900020 0006

[39]. Brown Jr, W. L. (1955). Ant Taxonomy. In: Kessel E.W. (Ed.). A Century of Progress in theNaturalSciences, California Academy of Sciences, San Francisco, pp. 1853-1953

[40]. Radchenko, A. G. (1997). Review of Ants of the Genus Cataglyphis Foerster (Hymenoptera, Formicidae) of Asia. [InRussian.].

Entomologicheskoe Obozrenie. 76: 424-442.
[41]. Bolton, S. (1994). Identification Guide to the Ant's Genera of the World. Harvard UniversityPress, Cambridge, MA 222. 41.

[42]. Bolton, G., Alpert, P. S. and Ward, P. (2006) Bolton's Catalogue of Ants of the World. HarvardUniversity Press, Cambridge, ISBN10: 9780674021518 , Massachusetts. 3658

[43]. Kelly, J.A., Van, D.I. and Anderson, G.S. (2009). The Influence of clothing and wrapping oncarcasees decomposition and arthropod succession: A winter study in Central Africa.Forensic Science Journal 41: $135-147$

[44]. Tullis, K., and Goff, M L. (1987). Arthropod succession in exposed carrion in a tropical rain foreston Oahu Island, Hawaii. Journal of Medical Entomology, 24: 332- 339.

[45]. Wolff, M., Uribe, A., Ortiz, A. and Duque, P.(2001). A preliminary study of forensic entomologyin Medell in, Colombia. Forensic Science International 120:53-59 